\title{
LAND CONSOLIDATIONS AS AN EFFECTIVE INSTRUMENT IN SOIL CONSERVATION
}

\author{
VÁCLAV KADLEC ${ }^{*}$ DANIEL ŽİŽALA, IVAN NOVOTNÝ, DARINA HEŘMANOVSKÁ, \\ JIŘÍ KAPIČKA, MARTIN TIPPL
}

Research Institute for Soil and Water Conservation, Žabovřeská 250, 15627 Praha 5 - Zbraslav, Czech Republic; e-mail: kadlec.vaclav@vumop.cz

*Author for correspondence

\begin{abstract}
Kadlec V., Žížala D., Novotný I., Heřmanovská D., Kapička J., Tippl M.: Land consolidations as an effective instrument in soil conservation. Ekológia (Bratislava), Vol. 33, No. 2, p. 188-200, 2014.

In the Czech Republic, more than $50 \%$ of agricultural land is threatened by water erosion, which is tremendously increasing during last couple of years. Therefore, it is necessary to deal with soil conservation as soon as possible. Land consolidations (LCs) are thus an important tool for implementation of soil, water and landscape conservation measures. It is possible to arrange land ownerships by them. They also arrange land spatially and functionally, provide availability of parcels and their land use in public interest. Besides that, environmental improvement, soil conservation, water management and increase in landscape ecological stability supplement the use of LCs. The results of soil consolidations serve for renewal of cadastral records and for the backgrounds for landscape planning.

The aim of the research was to evaluate the selected site (district Plzeň - South) with regard to the amounts and limits of proposed and implemented measures in LC process. The research was processed on the basis of detailed analysis regarding erosion risk and runoff conditions in GIS compared with the previous data (before LC).
\end{abstract}

Key words: GIS, erosion control measures, landscape management, Plzeň - South.

\section{Introduction}

Agricultural soil fund is a fundamental natural treasure of the Czech Republic; it is an irreplaceable natural tool enabling agriculture production and it is one of the main parts of the environment. The most important soil degradation process is erosion.

In the Czech Republic, according to the Research Institute for Soil and Water Conservation, up to $51 \%$ of agricultural soil fund is threatened by water erosion. Soil erosion deprives agricultural soils of the most productive part, i.e. topsoil. It deteriorates physical-chemical soil characteristics, reduces soil profile depth, increases skeleton content, decreases nutrient and humus content, damages plants and crops (Lobo et al., 2005). It also causes damages of many millions in urban zones and villages (Pimentel et al., 1995). In last 30 years, soil degra- 
dation as a result of water erosion has continued very rapidly and that is why it is important to protect soil from water erosion.

Our aim is to maintain sustainable soil management not only for contemporary generation, but also for future generations and to reduce damages caused by water erosion in urban zones, infrastructure and water sources. The agricultural land which is threatened by water erosion must be protected by suitable erosion control measures. In most cases it includes a complex of organisational, agro-technical and technical measures, those are mutually complement and respect basic requirements and possibilities of agriculture.

One of the effective and available tools for erosion and flood control is land consolidations (LCs). LCs arrange the land parcels spatially and functionally, consolidate or split them up to provide conditions for effective management of land owners. Besides that, environmental improvement, soil conservation, water management and increase in landscape ecological stability supplement the use of LC. The arrangement of the owner's rights and servitudes is a part of the LC process.

LCs are considered as a good development way of agri-environmental politics not only in the Czech Republic but also in other European countries, which is proved by many studies all around the world. The objectives of LC procedure are influenced by specific conditions in different countries, like historical, political and social development and natural conditions (Bonfanti et al., 1997; Crecente et al., 2002; Gorton, White, 2003). Post-socialist countries in Central and Eastern Europe have undergone radical land reforms after 1990. The majority of these countries transfer land rights from state farms and cooperatives to individual farms. Problems of LC in these countries are delineated by Swinnen (1999), Lerman (2001) or van Dijk (2007), further descriptions were brought separately about Hungary (Vranken, Swinnen, 2006), the Czech Republic (Sklenička, 2006; Prager et al., 2012), Eastern Germany (Prager et al., 2012), Poland (Zgłobicki, Baran-Zgłobicka, 2012), Bulgaria (Yanakieva, 2007; Di Falco et al., 2010; Prager et al., 2012), Albania (Sikor et al., 2009; Deininger et al., 2012), Lithuania (Pašakarnis, Maliene, 2010), Moldova (Gorton, White, 2003) or Croatia (Vjekoslav et al., 2008). Different development of the rest of European continent is denoted by Vitikainen (2004), who brings an overview of LC processes in Western Europe, mainly Finland, Germany, the Netherlands and Sweden. Despite the differences in various countries, general aims of LCs remain the same. The main objective of LC is to improve land arrangement and to promote the appropriate use of the real estate (Vitikainen, 2004). This component is referred as land reallocation or land readjustment (Demeteriou et al., 2012). The second part of LC, known as agrarian special planning, involves improvement of roads, drainage and irrigation systems, different building, landscaping, environmental management and conservation project, erosion control and other functions (Mihara, 1996; Miranda et al., 2006; Demeteriou et al., 2012). Vitikainen (2004) brings more detailed overview of LC objectives. In the Czech Republic, the LC projects in two basic forms are implemented (Sklenicka et al., 2009): (1) simple LC, dealing mostly with the provisional land use and (2) the comprehensive land consolidation (CLC), dealing with the changes in land ownership, landscape conservation, land reclamation, flood control, road systems, etc. One of the objectives of LC is to eliminate the unfavourable effects of runoff, especially soil erosion (Mihara, 1996), because in recent decades, water erosion and the flooding of villages with muddy water has increased due to 
narrower crop rotation, the up-scaling of agriculture in combination with LC, the disappearance of landscape elements, more heavy mechanisation and increase in the impervious surfaces area (Spaan et al., 2006). Soil protective measures are solved within the CLC through the plan of common measures.

The basic set of erosion control measures must be solved already at CLC, because the principles of the proposal have to be mutually harmonised with transport infrastructure, water, drainage and irrigation systems, needs of landscape creation and conservation, environmental conservation and also with the owners and tenants requirements.

The purpose of erosion control measures comes from hydrological assessment of all basins, from contemporary parcels arrangement and their land use. The proposal of erosion control measures can be made according to two major strategies (Rey, 2009): (1) controlling erosion on slopes (e.g. Bailey et al., 2013) and (2) allowing erosion to occur on slopes but retaining the eroded and transported material (e.g. Nyssen et al., 2000). The proposal of their parameters is given by the methodologies and it is based on modern water and wind erosion knowledge (Mendez, Buschiazzo, 2010; Janeček et al., 2012a). The purpose of measures should be done with regard to landscape character, its typical elements and the needs in the ecological stability increase and with the highest efficiency of measures at minimal confiscation of the agricultural land. That means to interconnect each proposed functions in the meaning of their multi-functionality. The design of those measures should be developed with respect to landscape type, capacities and limits.

However, the process of CLC is quite prolonged and too complicated. That is why the CLC is, according to the statistics of the Ministry of Agriculture (2011), completed only at $<9 \%$ cadastral municipalities and all in all they had been solved or are being solved only at $31 \%$ cadastral municipalities.

Only after 20 years of LCs, it is possible to evaluate the effectiveness of implemented measure within the plan of common measure. Therefore the project NAZV (National Agency for Agriculture Research) Q191C008 'Optimization of procedures of the design of technical erosion control measures' was initiated in the year 2009. The aim of the project is to inventorying existing and intended technical soil erosion measures in the Czech Republic.

\section{Material and methods}

The district Plzeň - South was chosen as a research site. It lies in the South-West part of Plzeň region. The site has an area of $990 \mathrm{~km}^{2}$, i.e. it represents $13.1 \%$ of the region's area. The site lies in hilly area, its medium part in Přeštickoblovická highlands. The eastern part is composed by Brdská highlands with its highest point 'Above Marásek' (802 $\mathrm{m}$ above sea level). Geologically it consists of sediment rock of Algonkian up to Devonian ages - schist and phyllites, phthanites sand limestone. Also sometimes granite and its varieties are found. The most common soil types are Cambisols (57\%), Albeluvisols (19\%) and Luvisols (18\%). Soils are mostly medium textured. The climate is continental with longer periods of droughts. The district lies in moderately warm climatic region. Around $60.1 \%$ of the district's area is used for agriculture and $30.2 \%$ is forested. According to the Czech statistical office $3.515 \mathrm{~km}^{2}$ of the district were used for cultivation in the year 2010. Regarding erosion-susceptible plants mainly oilseed rape ( $3588 \mathrm{ha}$ ) was cultivated, then maize (4181 ha mainly for silage and fodder crop), sunflower (405 ha) and potatoes (186 ha). All in all, erosion-susceptible plants were cultivated on one third of the area.

The Plzen - South district consists of 186 land units. According to the Ministry of Agriculture only 69 CLC were developed (closed or open) in this district after 20 years of LCs that represents $37.07 \%$ of the total number of cadastral units of the district. The level of semi-finished CLC within the district is expressed in Table 1 and Fig. 1. 
This study has evaluated the cadastral units only with completed CLC. Detailed information about the implementation of plan of common measures proposed within CLC was not available at four cadastral units yet. Therefore the analysis was carried out only in 18 cadastral units.

$\mathrm{T}$ a b l e 1. The summary of complex land consolidations in the Plzeň-South District to the date of 31.12.2011 (the Ministry of Agriculture of the Czech Republic).

\begin{tabular}{|l|c|c|c|c|}
\hline \multicolumn{5}{|c|}{ The summary of CLC to the date of 31.12.2011 in the Plzeň-South District } \\
\hline & $\begin{array}{c}\text { The number of } \\
\text { cadastral units }\end{array}$ & $\begin{array}{c}\text { The ratio of } \\
\text { cadastral units (\%) }\end{array}$ & $\begin{array}{c}\text { The area of cadastral } \\
\text { units }\left(\mathrm{km}^{2}\right)\end{array}$ & $\begin{array}{c}\text { The extent of } \\
\text { cadastral units (\%) }\end{array}$ \\
\hline Closed CLC & 22 & 11.83 & 114.16 & 11.53 \\
\hline Open CLC & 23 & 12.34 & 137.15 & 13.85 \\
\hline CLC in preparation & 24 & 12.90 & 86.77 & 8.76 \\
\hline $\begin{array}{l}\text { Total cadastral } \\
\text { units in the district }\end{array}$ & $\mathbf{1 8 6}$ & & $\mathbf{9 9 0 . 0 4}$ & \\
\hline
\end{tabular}

\section{General Map of Complex Land Consolidations in the Plzen̆-South District}

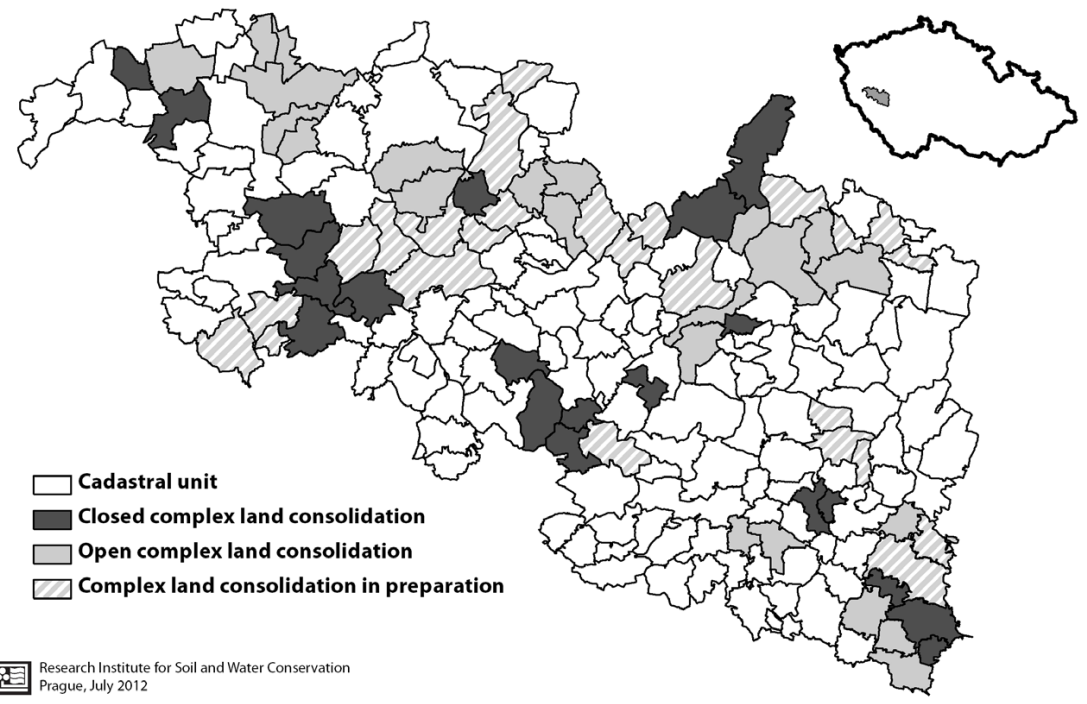

Fig. 1. The map of complex LCs in the Plzen - South district to the date of 31 December 2011 (the Ministry of Agriculture of the Czech Republic).

On this site a pilot study within the project 'Revision of the purposes of erosion protective and flood control measures within approved common measures of CLC' for the needs of the Central Land Office and possible implementation to the next information systems of the Ministry of Agriculture was done. Within this project the revision of the elements of erosion and flood control measures proposed within the plan of common measure was done at completed complex LCs. It included technical and organisational measures with primary or secondary (road network) protective erosion function. The agro-technical measures were also observed, but due to problematic control they were not included in the evaluation. The proposed elements were processed in the ArcGIS software and recorded into geodatabase. All the relevant attributes were recorded for each measure.

Detailed analysis with respect to erosion risks and runoff conditions were done in the investigated sites. The analysis of water erosion risk was based on the calculations of long-term soil loss using the Universal Soil Loss 
Equation (USLE) (Wischmeier, Smith, 1978). We evaluated conditions without the measures, with currently implemented elements and conditions with assumed implementation of all proposed measures within the plan of common measures. All of the computing methods were done in the ArcGIS software with Spatial Analyst extension.

Within the calculation of erosion risk by the USLE, each factor entering the calculation was gained as follows:

- $\quad$ K factor - soil erodibility, which was determined on the basis of the layer of evaluated soil ecological units (ESEU) and managed by the Research Institute for Soil and Water Conservation in a scale of 1:5000. The determining parameter of ESEU code is the number of main soil unit. According to the main soil unit the value of soil erodibility is determined.

- $\quad \mathrm{R}$ factor - the rainfall erosion index was based on long-term rainfall observations by Czech Hydrometeorological Institute and determined as an average annual value of $20 \mathrm{MJ} \mathrm{ha}^{-1} \mathrm{~cm} \mathrm{~h}^{-1}$ for the whole area of the Czech Republic (Janeček et al., 2007).

- $\quad \mathrm{C}$ factor - crop/vegetation and management factor was processed on the basis of climatic regions according to the Kadlec and Toman (2002) on arable land, and the values for permanent grassland where completed.

- $\quad$ LS factor - the slope-length gradient factor was created on the basis of calculations using USLE 2D model by McCool method (McCool et al., 1989) using runoff algorithm Flux Decomposition. This was done using geoinformational layers of Digital Terrain Model (DMT) by GEODIS Company in a grid of $10 \mathrm{~m}$ and by using actual layer of soil units of the Land Parcel Identification System (LPIS) database and land cover from the Corine Land Cover database for the year 2006.

- $\quad$ Factor $\mathrm{P}$ - the support practise factor was not considered in the calculation. Each erosion control measure enters the calculations as a change in crop and management factor $(C)$ if there was a change in vegetation cover (e.g. by grassing) or as a change in input layers for the calculation of LS factor if the element interrupts surface runoff.

Design and implemented parameters were not considered in this context and the impact of each measure on surface runoff interruption and thus efficient estate length was expertly considered only.

In the next phase, the impact of erosion and flood control measures on decrease in long-term average soil loss (in $\mathrm{t} \mathrm{ha}^{-1}$ year $^{-1}$ ) for each cadastral unit was evaluated. The three variants were compared: without measures, with implemented measures and with all proposed measures. On the basis of GIS analysis, the changes in long-term soil loss in each cadastral unit for the three mentioned alternatives were computed due to the evaluation of the impact of plan of common measures implementation and suitable placement of the measures.

\section{Results}

The research area is situated in the Plzen - South district at 18 cadastral units with closed LCs. Table 2 is a summary of suggested and implemented measures proposed within the plan of common measures. Table 2 shows that 103 measures were proposed with primary or secondary (alternatively additional) erosion control function within 18 CLC. Up to now, only 68 of these measures have been implemented. According to the land office, the reasons are that either these measures were in the order for implementation, or there is no money or no interest among land owners and users.

The most proposed and mainly implemented measures are field roads, which make units accessible and secondarily when the drainage system is designed appropriately, the roads also protect soil from erosion. Regarding soil erosion control measures there are mainly grassed areas, grassed waterways and infiltration belts. These elements enter into the calculation of long-term soil loss as a change in the value of support practice factor from arable land to permanent grasslands. Contrarily, water management measures, as interception ditches, soakage pits or protective reservoirs were in the calculations considered as the elements which interrupt surface runoff. That means they have the impact on the decrease in slope length, or rather topographic LS factor. The impact of field roads was solved by the same way. 
$\mathrm{T} \mathrm{a} \mathrm{b}$ le 2 . The number and extent of proposed common measures in each cadastral unit.

\begin{tabular}{|c|c|c|c|c|c|c|c|c|}
\hline \multicolumn{9}{|c|}{ Proposed common measures } \\
\hline \multirow[t]{2}{*}{ Cadastral unit } & \multirow{2}{*}{ 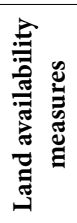 } & \multirow{2}{*}{ 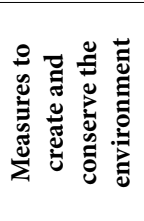 } & \multicolumn{2}{|c|}{$\begin{array}{l}\text { Erosion control } \\
\text { measures }\end{array}$} & \multirow{2}{*}{ 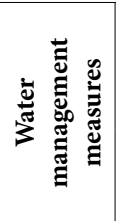 } & \multirow{2}{*}{ 离 } & \multirow{2}{*}{ 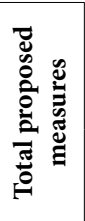 } & \multirow{2}{*}{ 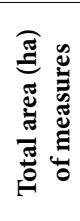 } \\
\hline & & & Areal & Linear & & & & \\
\hline $\begin{array}{l}\text { Total number } \\
\text { of measures in } 18 \mathrm{ca}- \\
\text { dastral units }\end{array}$ & 30 & 3 & 23 & 32 & 15 & 68 & 103 & 209.94 \\
\hline Březí u Žinkov & 2 & & & & & 2 & 2 & 1.21 \\
\hline Čmelín & 3 & & 3 & & 1 & 7 & 7 & 17.61 \\
\hline Hradec u Stoda & 2 & & & & 1 & 0 & 3 & 5.74 \\
\hline Hradiště u Kasejovic & 5 & 1 & & 4 & 2 & 10 & 12 & 21.35 \\
\hline Hradištský Újezd & & & 1 & 1 & & 2 & 2 & 4.95 \\
\hline Lišice u Dolní Lukavice & 2 & & 3 & 2 & & 1 & 7 & 12.86 \\
\hline Milínov u Nezvěstic & & 1 & 3 & 2 & 1 & 7 & 7 & 41.05 \\
\hline Mírovice & 1 & & 1 & & & 0 & 2 & 3.37 \\
\hline Polánka u Kasejovic & & 1 & 2 & 1 & & 0 & 4 & 13.52 \\
\hline Přestavlky u Dnešic & & & 3 & 2 & & 5 & 5 & 20.68 \\
\hline Roupov & 3 & & & 4 & 2 & 1 & 9 & 3.88 \\
\hline Skašov & 3 & & & & 1 & 3 & 4 & 2.42 \\
\hline Skočice u Přeštic & 2 & & 3 & 7 & 2 & 9 & 14 & 34.64 \\
\hline Soběkury & 1 & & & 2 & 3 & 6 & 6 & 5.09 \\
\hline Svárkov & & & 1 & 1 & & 2 & 2 & 1.72 \\
\hline Újezd u Horšic & & & 2 & & 1 & 3 & 3 & 11.42 \\
\hline Víska & 1 & & & 1 & & 0 & 2 & 0.15 \\
\hline Žákava & 4 & & 1 & 4 & 1 & 10 & 10 & 8.28 \\
\hline
\end{tabular}

In selected cadastral units, the conditions without measures (variant A), with actually realised elements (B) and proposed conditions at implementation of all proposed measures within common measures $(\mathrm{C})$ were done.

Due to the fact that for the visualisation of the results the scale of the whole district was unclear, we have chosen a cadastral unit Skočice u Přeštic (Fig. 2) as a graphical expression of the impact of erosion control measures on long-term average soil loss and also the set of infiltration belts in cadastral unit Roupov (Fig. 3) for more detailed view.

In the cadastral unit Skočice u Přeštic, the complex LC was completed in the year 2007. Up to now, grassed infiltration belts and protective grassing and afforestation were implemented here. The proposed measures like field roads, stream restoration and protective retention reservoirs are planned in the next years. Fig. 3 shows potential water erosion risk of the cadastral before the CLC, current condition with up to now realised measures and the conditions with all proposed measures within the plan of common measures.

Tables 3-5 show selected cadastral units with closed CLC. The complex consolidations were divided into six degrees of water erosion risk. As a threshold value, the permissible soil 
The Cadastral unit - Skočice u Přeštic

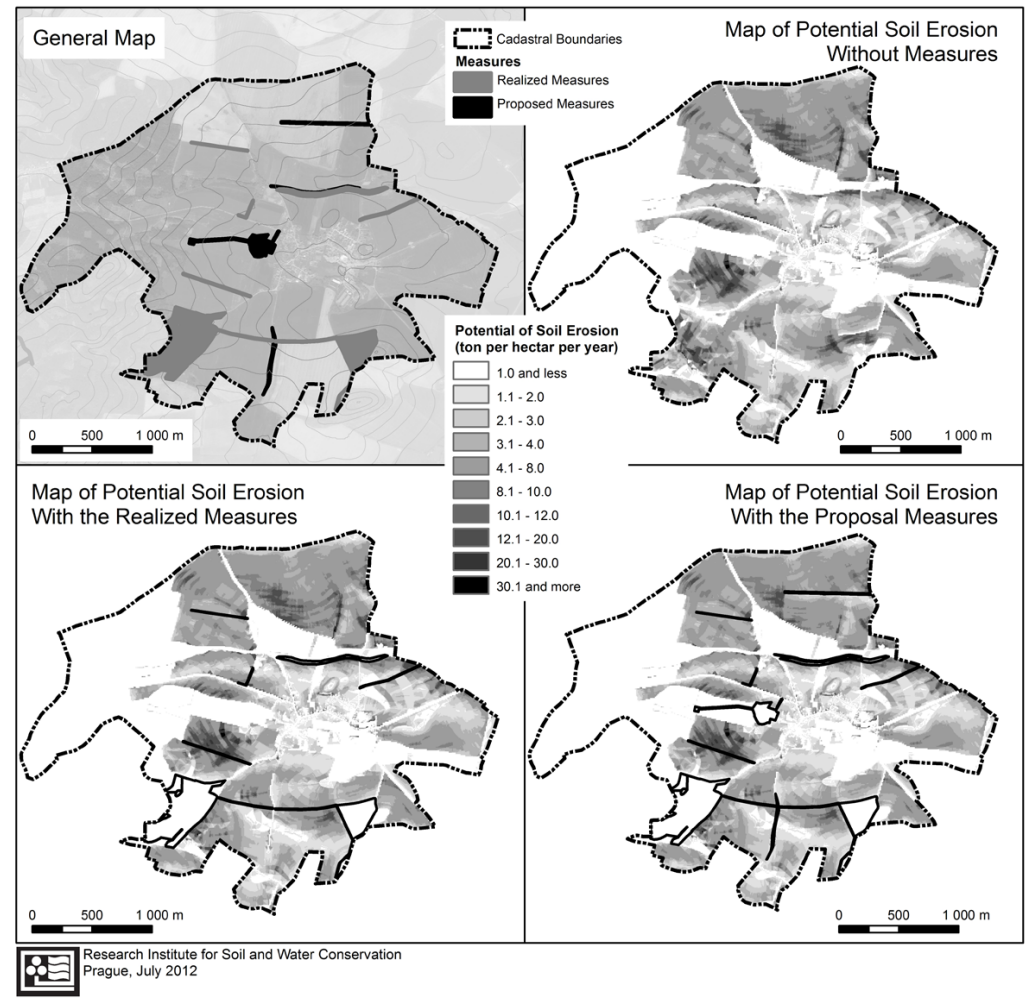

Fig. 2. The map of potential water erosion risk at cadastral unit Skočice $u$ Přeštic.

loss by water erosion was set to 4 or $10 \mathrm{t} \mathrm{ha}^{-1}$ year $^{-1}$, for medium deep and deep soils, respectively.

Variants A (before complex LC) and variants C (after the implementation of all proposed measures within common measures) are compared in the tables. The object of the analysis was only organisational (mainly grassing or afforestation) measures. The areal representation of each category of long-term average soil loss $(G)$ is expressed in percentage. These results were mutually compared.

Considering the implementation of all proposed measures within the plan of common measures, the areas decreased where $G$ was higher than 4.1 or $10.1 \mathrm{t} \mathrm{ha}^{-1}$ year $^{-1}$. That was given mainly by the fact that measures within the plan of common measures were proposed just for the threatened areas, where $\mathrm{G}$ was higher than 4 or $10 \mathrm{t} \mathrm{ha}^{-1} \mathrm{year}^{-1}$. Considering the implementation of all proposed measures within the plan of common measures, the total agricultural soil area was also reduced. The area was reduced by areas of newly proposed field roads, water reservoirs and forested lands. These sites do not enter the calculation of erosion risk as agricultural soils anymore. 


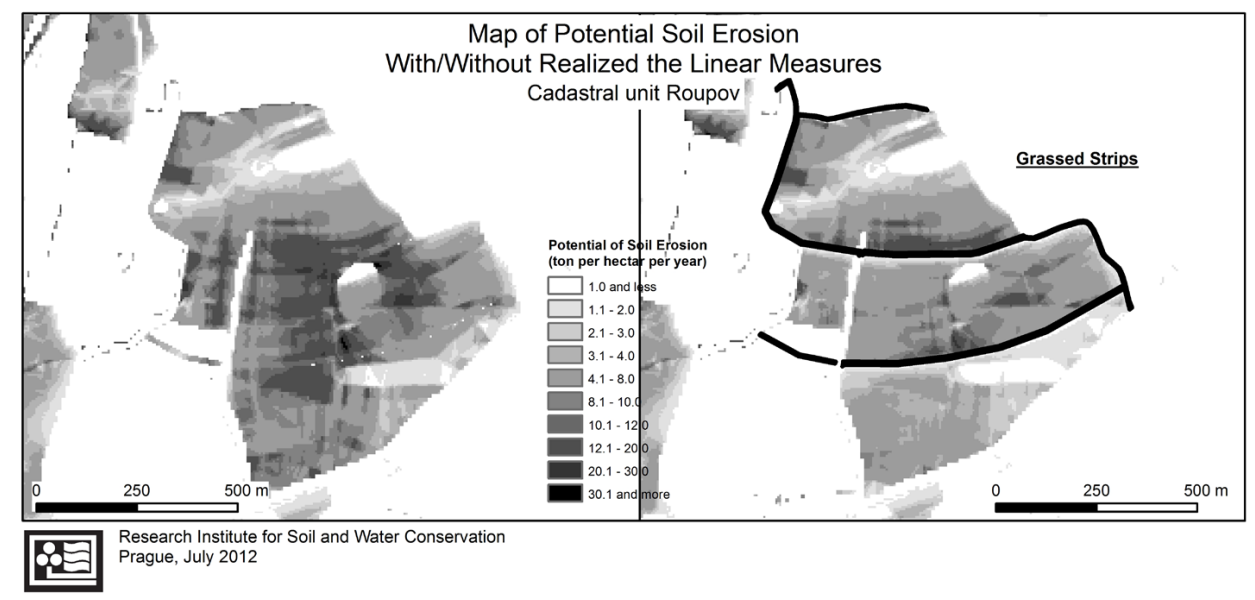

Fig. 3. Detailed scale of the efficiency of infiltration grassland belts for decreasing of potential water erosion risk (the example of cadastral unit Roupov).

$\mathrm{T}$ a b le 3 . The areal representation (in \%) of categories of long-term average soil loss in each cadastral units before the land consolidation implementation (Variant A).

\begin{tabular}{|l|c|c|c|c|c|c|c|}
\hline $\begin{array}{l}\text { Long-term average soil } \\
\text { loss (G) (t/ha/year) }\end{array}$ & $\mathbf{1 . 0}$ & $\mathbf{1 . 1} \mathbf{- 2 . 0}$ & $\mathbf{2 . 1} \mathbf{- 4 . 0}$ & $\mathbf{4 . 1} \mathbf{- 8 . 0}$ & $\mathbf{8 . 1} \mathbf{- 1 0 . 0}$ & $>\mathbf{1 0 . 1}$ & $\begin{array}{c}\text { In total } \\
\text { (ha) }\end{array}$ \\
\hline $\begin{array}{l}\text { Total value in 18 } \\
\text { cadastral units }\end{array}$ & $\mathbf{3 7 . 9 \%}$ & $\mathbf{1 7 . 2 \%}$ & $\mathbf{2 2 . 0 \%}$ & $\mathbf{1 6 . 1} \%$ & $\mathbf{3 . 0 \%}$ & $\mathbf{3 . 8 \%}$ & $\mathbf{5 9 0 7 . 3}$ \\
\hline Březí u Žinkov & $63.8 \%$ & $8.9 \%$ & $12.1 \%$ & $11.5 \%$ & $1.9 \%$ & $1.7 \%$ & 369.0 \\
\hline Čmelíny & $63.4 \%$ & $17.5 \%$ & $14.2 \%$ & $4.1 \%$ & $0.4 \%$ & $0.5 \%$ & 151.8 \\
\hline Hradec u Stoda & $31.8 \%$ & $29.3 \%$ & $24.0 \%$ & $11.4 \%$ & $1.6 \%$ & $1.9 \%$ & 420.8 \\
\hline Hradiště u Kasejovic & $40.6 \%$ & $24.7 \%$ & $22.6 \%$ & $10.1 \%$ & $1.0 \%$ & $1.0 \%$ & 492.6 \\
\hline Hradištský Újezd & $24.1 \%$ & $22,7 \%$ & $23.0 \%$ & $20.3 \%$ & $5.2 \%$ & $4.7 \%$ & 143.1 \\
\hline Lišice u Dolní Lukavice & $17.9 \%$ & $13.3 \%$ & $21.9 \%$ & $22.7 \%$ & $6.7 \%$ & $17.6 \%$ & 277.1 \\
\hline Milínov u Nezvěstic & $33.0 \%$ & $15.9 \%$ & $21.9 \%$ & $20.4 \%$ & $3.9 \%$ & $4.8 \%$ & 336.4 \\
\hline Mířovice & $29.4 \%$ & $18.8 \%$ & $26.7 \%$ & $19.0 \%$ & $3.0 \%$ & $3.0 \%$ & 273.2 \\
\hline Polánka u Kasejovic & $38.1 \%$ & $18.4 \%$ & $26.0 \%$ & $12.5 \%$ & $1.6 \%$ & $3.5 \%$ & 155.2 \\
\hline Přestavlky u Dnešic & $26.1 \%$ & $25.4 \%$ & $28.7 \%$ & $16.7 \%$ & $1.7 \%$ & $1.4 \%$ & 444.0 \\
\hline Roupov & $55.0 \%$ & $7.2 \%$ & $12.8 \%$ & $15.4 \%$ & $4.4 \%$ & $5.1 \%$ & 461.4 \\
\hline Skašov & $60.1 \%$ & $12.3 \%$ & $17.7 \%$ & $8.0 \%$ & $0.8 \%$ & $1.1 \%$ & 389.8 \\
\hline Skočice u Přeštic & $14.1 \%$ & $13,4 \%$ & $28.2 \%$ & $31.8 \%$ & $6.3 \%$ & $6.1 \%$ & 492.7 \\
\hline Soběkury & $31.5 \%$ & $28,7 \%$ & $27.1 \%$ & $10.8 \%$ & $1.1 \%$ & $0.8 \%$ & 401.9 \\
\hline Svárkov & $55.6 \%$ & $15,2 \%$ & $14.7 \%$ & $11.3 \%$ & $1.9 \%$ & $1.3 \%$ & 201.6 \\
\hline Újezd u Horšic & $26.2 \%$ & $9.9 \%$ & $18.7 \%$ & $26.8 \%$ & $9.0 \%$ & $9.4 \%$ & 261.7 \\
\hline Víska & $74.1 \%$ & $7.9 \%$ & $10.3 \%$ & $5.4 \%$ & $0.7 \%$ & $1.6 \%$ & 67.8 \\
\hline Žákava & $36.6 \%$ & $12.8 \%$ & $26.8 \%$ & $17.2 \%$ & $2.0 \%$ & $4.5 \%$ & 567.2 \\
\hline
\end{tabular}


$\mathrm{T} \mathrm{a} \mathrm{b} \mathrm{l} \mathrm{e} \mathrm{4.} \mathrm{The} \mathrm{areal} \mathrm{representation} \mathrm{(in} \mathrm{\% )} \mathrm{of} \mathrm{categories} \mathrm{of} \mathrm{long-term} \mathrm{average} \mathrm{soil} \mathrm{loss} \mathrm{in} \mathrm{each} \mathrm{cadastral} \mathrm{units} \mathrm{after}$ the implementation of all proposed measures within the plan of common measures (Variant C).

\begin{tabular}{|l|c|c|c|c|c|c|c|}
\hline $\begin{array}{l}\text { Long-term average soil } \\
\text { loss (G) (t/ha/year) }\end{array}$ & $\mathbf{1 . 0}$ & $\mathbf{1 . 1} \mathbf{- 2 . 0}$ & $\mathbf{2 . 1} \mathbf{- 4 . 0}$ & $\mathbf{4 . 1} \mathbf{- 8 . 0}$ & $\mathbf{8 . 1 - 1 0 . 0}$ & $\mathbf{1 0 . 1}$ & $\begin{array}{c}\text { In total } \\
\text { (ha) }\end{array}$ \\
\hline $\begin{array}{l}\text { Total value in 18 } \\
\text { cadastral units }\end{array}$ & $\mathbf{4 0 . 3} \%$ & $\mathbf{1 7 . 1 \%}$ & $\mathbf{2 1 . 4 \%}$ & $\mathbf{1 5 . 4 \%}$ & $\mathbf{2 . 7 \%}$ & $\mathbf{3 . 2 \%}$ & $\mathbf{5 8 6 4 . 0}$ \\
\hline Březí u Žinkov & $63.9 \%$ & $8.9 \%$ & $12.0 \%$ & $11.5 \%$ & $1.9 \%$ & $1.7 \%$ & 367.6 \\
\hline Čmelíny & $71.0 \%$ & $14.6 \%$ & $10.6 \%$ & $3.2 \%$ & $0.3 \%$ & $0.4 \%$ & 151.5 \\
\hline Hradec u Stoda & $32.0 \%$ & $29.8 \%$ & $23.5 \%$ & $11.4 \%$ & $1.6 \%$ & $1.7 \%$ & 417.7 \\
\hline Hradiště u Kasejovic & $43.5 \%$ & $24.5 \%$ & $21.2 \%$ & $8.9 \%$ & $1.0 \%$ & $0.9 \%$ & 486.6 \\
\hline Hradištský Ujjezd & $27.3 \%$ & $22.4 \%$ & $22.5 \%$ & $18.7 \%$ & $4.8 \%$ & $4.2 \%$ & 143.1 \\
\hline Lišice u Dolní Lukavice & $18.6 \%$ & $13.6 \%$ & $22.4 \%$ & $23.4 \%$ & $6.7 \%$ & $15.3 \%$ & 267.2 \\
\hline Milínov u Nezvěstic & $43.3 \%$ & $14.1 \%$ & $18.9 \%$ & $16.7 \%$ & $3.2 \%$ & $3.7 \%$ & 336.2 \\
\hline Mírovice & $30.5 \%$ & $19.1 \%$ & $26.4 \%$ & $18.4 \%$ & $2.8 \%$ & $2.9 \%$ & 271.9 \\
\hline Polánka u Kasejovic & $43.8 \%$ & $16.4 \%$ & $23.9 \%$ & $11.1 \%$ & $1.4 \%$ & $3.4 \%$ & 155.2 \\
\hline Přestavlky u Dnešic & $29.6 \%$ & $24.6 \%$ & $27.4 \%$ & $15.4 \%$ & $1.6 \%$ & $1.4 \%$ & 444.0 \\
\hline Roupov & $55.9 \%$ & $7.7 \%$ & $13.4 \%$ & $16.5 \%$ & $3.5 \%$ & $2.9 \%$ & 456.8 \\
\hline Skašov & $60.1 \%$ & $12.3 \%$ & $17.7 \%$ & $8.0 \%$ & $0.8 \%$ & $1.1 \%$ & 388.8 \\
\hline Skočice u Přeštic & $17.6 \%$ & $13.3 \%$ & $28.0 \%$ & $31.6 \%$ & $5.1 \%$ & $4.3 \%$ & 481.0 \\
\hline Sob̌̌kury & $32.2 \%$ & $28.5 \%$ & $26.8 \%$ & $10.6 \%$ & $1.1 \%$ & $0.8 \%$ & 400.7 \\
\hline Svárkov & $56.2 \%$ & $15.1 \%$ & $14.4 \%$ & $11.1 \%$ & $1.9 \%$ & $1.3 \%$ & 201.6 \\
\hline Újezd u Horšic & $30.2 \%$ & $9.7 \%$ & $18.1 \%$ & $25.4 \%$ & $8.4 \%$ & $8.2 \%$ & 261.6 \\
\hline Víska & $74.1 \%$ & $7.9 \%$ & $10.3 \%$ & $5.4 \%$ & $0.7 \%$ & $1.6 \%$ & 67.8 \\
\hline Ž́kava & $37.4 \%$ & $13.7 \%$ & $26.4 \%$ & $16.3 \%$ & $2.1 \%$ & $4.1 \%$ & 564.7 \\
\hline
\end{tabular}

According to the Table 3 it is possible to determine which cadastral units are most threatened by water erosion. In the investigated sites, 45 cadastral units had G $>4.0 \mathrm{t} \mathrm{ha}^{-1}$ year $^{-1}$ at more than one third of the agricultural soil area. The most threatened cadastral units are Skočice u Přštic ( $44.2 \%$ of the area of agricultural soil with $\mathrm{G}>4.0 \mathrm{t} \mathrm{ha}^{-1}$ year $^{-1}$ ), Ujezd u Horšic (45.2\%) and Lišice u Dolní Lukavice (47.0\%). The variant without erosion control measures was compared with the values of $G$ calculated for the conditions of all proposed erosion control measures. Table 5 summarises the results of the calculations of long-term average soil loss on cadastral units according to each variant.

Total long-term soil loss at all investigated cadastral units before realisation of CLC was $16,068 \mathrm{t} \mathrm{year}^{-1}$. After the implementation of all proposed measures within the plan of common measures the soil loss would decrease by $8 \%$.

\section{Discussion}

As it is visible from the figures, the efficiency of these measures was positively expressed in decrease of soil loss. However, not only these measures as individual elements solve sufficiently the water erosion risk of these areas. While solving erosion control measures, it is thus important to come out of the principle of proposing the complex system of erosion control measures, which consists of organisational, agro-technical and technical measures. 
T a b l e 5. Long-term average soil loss $(G)$ in cadastral (t.year $\left.{ }^{-1}\right)$.

\begin{tabular}{|c|c|c|c|c|c|c|c|}
\hline \multirow[b]{3}{*}{ Cadastral unit } & \multirow{3}{*}{ 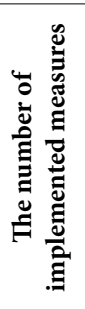 } & \multirow{3}{*}{ 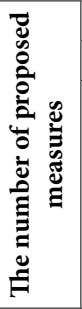 } & \multicolumn{5}{|c|}{ Long-term average soil loss G [t.year-1] } \\
\hline & & & \multirow[b]{2}{*}{ 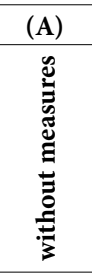 } & \multirow{2}{*}{$\begin{array}{l}\text { (B) } \\
\\
\\
\end{array}$} & \multirow{2}{*}{ 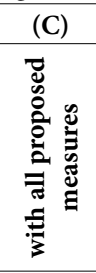 } & \multicolumn{2}{|c|}{ Difference } \\
\hline & & & & & & 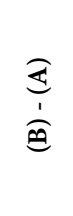 & $\begin{array}{l}\underset{S}{S} \\
\stackrel{1}{0}\end{array}$ \\
\hline Total values at 18 cadastral units & 68 & 103 & 16068 & 15154 & 14781 & -915 & -1288 \\
\hline Březí u Žinkov & 2 & 2 & 614 & 610 & 609 & -4 & -5 \\
\hline Čmelíny & 7 & 7 & 169 & 135 & 135 & -34 & -34 \\
\hline Hradec u Stoda & 0 & 3 & 966 & 966 & 946 & 0 & -20 \\
\hline Hradiště u Kasejovic & 10 & 13 & 934 & 866 & 865 & -68 & -69 \\
\hline Hradištský Újezd & 2 & 2 & 471 & 442 & 443 & -28 & -28 \\
\hline Lišice u Dolní Lukavice & 1 & 7 & 1626 & 1625 & 1401 & -1 & -225 \\
\hline Milínov u Nezvěstic & 7 & 7 & 1045 & 870 & 868 & -175 & -177 \\
\hline Mířovice & 0 & 2 & 808 & 808 & 782 & 0 & -26 \\
\hline Polánka u Kasejovic & 0 & 4 & 374 & 374 & 343 & 0 & -31 \\
\hline Přestavlky u Dnešic & 5 & 5 & 1122 & 1064 & 1064 & -58 & -58 \\
\hline Roupov & 1 & 9 & 1161 & 1012 & 1010 & -149 & -151 \\
\hline Skašov & 3 & 4 & 584 & 583 & 583 & -1 & -1 \\
\hline Skočice u Přeštic & 9 & 14 & 2092 & 1930 & 1864 & -161 & -228 \\
\hline Soběkury & 6 & 6 & 836 & 824 & 824 & -12 & -12 \\
\hline Svárkov & 2 & 2 & 345 & 341 & 341 & -4 & -4 \\
\hline Újezd u Horšic & 3 & 3 & 1170 & 1072 & 1072 & -98 & -98 \\
\hline Víska & 0 & 2 & 78 & 78 & 78 & 0 & 0 \\
\hline Žákava & 10 & 11 & 1674 & 1554 & 1554 & -120 & -120 \\
\hline
\end{tabular}

In the year 2012, the methodology of soil erosion-control from the year 2007 (Janeček et al., 2007) was revised. Among others, the threshold limits of soil loss and new average annual value of $\mathrm{R}$ factor were newly determined. The $\mathrm{R}$ factor for the whole Czech Republic was determined as $40 \mathrm{MJ} \mathrm{ha}^{-1} \mathrm{~cm} \mathrm{~h}^{-1}$ (Janeček et al., 2012b).

The threshold values for permissible soil loss for shallow, medium deep and deep soils are determined by Janeček et al. (2012a) as follows: the lands with shallow soils (up to $30 \mathrm{~cm}$ depths) should not be used for agriculture production, that is why it is recommended to convert them to permanent grasslands or forest. The value of permissible soil loss of $4 \mathrm{t} \mathrm{ha}^{-1} \mathrm{year}^{-1}$ is newly recommended to use for both medium deep soils $(30-60 \mathrm{~cm}$ ) and also for deep soils (above $60 \mathrm{~cm}$ ). The reason behind the decrease in permissible value for deep soils is the necessity to increase their conservation, because these soils belong to agriculturally most valuable (the most productive) soils. These revisions were not included into our analysis. In all 18 cadastral units of investigated area, LCs were finished until the year 2011, which means that all the proposals of measures considered with the values were stated by Janeček et al. (2007) - R factor for the whole country with the value of $20 \mathrm{MJ} \mathrm{ha}^{-1} \mathrm{~cm} \mathrm{~h}^{-1}$ and the values of permissible soil loss of 4 and $10 \mathrm{t} \mathrm{ha}^{-1} \mathrm{year}^{-1}$. 
By all means, with respect to soil conservation, the highest efficiency has protective grassing or afforestation. There is no undesirable erosion soil loss on these areas. But it is not possible to apply this system on the whole arable land, that is why the agro-technical measures such as mulching, sowing into stubble and no-tillage soil management are chosen. These ways support infiltration of water into soil and limit erosion. Stated evaluation of cadastral unit is taken only from the point of view of erosion soil loss. However, considered measures in investigated cadastral units also fulfil the other functions, like transformation of concentrated flow, which USLE equation does not take into account.

From the point of view of consideration of water erosion by the USLE equation, building of erosion-control manholes, ditches and erosion-control balks seem to be the least efficient, because they only divide unit into smaller parts and thus they prevent development of erosion events in lower parts of the unit and they take surface water out of the critical profiles. However while following these measures, soil has to be protected under and above the element by other erosion control measures.

Certainly different point of view on these measures is with regard to flood control and elimination of unfavourable impact of rainfalls. The best are biotechnical erosion-control elements, which are able to take extreme runoff amounts out of critical profiles. Grassed or cultivated lands by careful way cannot significantly influence surface runoff at extreme rainfalls. The effectiveness of these measures can be theoretically calculated according to the well-known methods and procedures. But their practical implication can be assessed usually only by verification of actual meteorological events, connected more or less with extreme weather conditions.

\section{Conclusion}

After the period of collectivisation of agriculture and violent confiscation of agricultural soil in the Czech Republic from 1950s till 1980s of the twentieth century, agricultural land development has gradually changed since the year 1989. The view of the agricultural soil conservation has changed, and construction and restoration measures contributing to its conservation have been made.

Among the measures, which are necessary at least for partial rectification of destroyed soil characteristics, the modification of water management conditions, the renewal of water courses and reservoirs, implementation of erosion and flood control, implementation of systems of ecological stability, renewal of groves, achievement of better availability of the areas by suitable selected field roads systems and last but not least achievement of esthetical level of the landscape for the purpose of increase of the quality in rural areas can be included.

However, the implementations of the whole series of elements and measures, which aim to floods and soil erosion prevention or to mitigation of their damages, collide with complicated ownerships very often. Under the intended constructions and elements there is a great amount of parcels, whose owners need not always agree with intended realisation of the proposal. LCs are thus suitable tool for solving of ownership and agro-environmental relationships. 
Although the process of LC is long-term and often complicated with many participants, their result is not only the approved plan of common measures and restored cadastral apparatus with arranged ownerships, but also the implementation of necessarily common measures.

The results of this study show that the effectiveness of the measures proposed within the CLC are expressed mainly on the areas highly threatened by soil erosion. The efficiency of the measures is proved by up to now known results, from which it is obvious that the effect of these measures within the basin area will be favourably demonstrated mainly in decreasing of soil loss level and the values of direct runoff and also in increasing of potential retention and total natural retention of basin.

These qualitative results are possible to assign the complex view of LC on the investigated sites. Complex view is also suitable base for erosion-control soil conservation in the Czech Republic, which is a complex of all set of agro-technical, organisational and technical measures, which followed each other and which are mutually complemented.

The result of these measures is balanced and stable agriculture landscape resistant against the consequences of extreme climatic events. As it is stated by Doležal et al. (2010), the process of LC has become very important tool aiming to conservation and creation of landscape and to maintain sustainable rural area development mainly because of the reason that it enables to unequivocally delimit owners' parcels for publicly beneficial measures and constructions with following implementation.

\section{Acknowledgements}

This study was made possible by the support of research project NAZV QI91C008 (70\%) and research plan MZE0002704902 (30\%).

\section{References}

Bailey, A., Deasy, C., Quinton, J., Silgram, M., Jackson, B. \& Stevens C. (2013). Determining the cost of in-field mitigation options to reduce sediment and phosphorus loss. Land Use Policy, 30, 234-242. DOI: 10.1016/j.landusepol.2012.03.027.

Bonfanti, P., Fregonese, A. \& Sigura M. (1997). Landscape analysis in areas affected by land consolidation. Landsc. Urban Plann., 37, 91-98. DOI: 10.1016/S0169-2046(96)00373-8.

Crecente, R., Alvarez, C. \& Fra U. (2002). Economic, social and environmental impact of land consolidation in Galicia. Land Use Policy, 19, 135-147. DOI: 10.1016/S0264-8377(02)00006-6.

Deininger, K., Savastano, S. \& Carletto C. (2012). Land fragmentation, cropland abandonment, and land market operation in Albania. World Development, 40(10), 2108-2122. DOI: 10.1016/j.worlddev.2012.05.010.

Demeteriou, D., Stillwell, J. \& See L. (2012). An integrated planning and decision support system (IPDSS) for land consolidation: theoretical framework and application of the land-redistribution modules. Environment and Planning B: Planning and Design, 39(4), 609-628. DOI: 10.1068/b37075.

Di Falco, S., Penov, I., Aleksiev, A. \& van Rensburg T.M. (2010). Agrobiodiversity, farm profits and land fragmentation: Evidence from Bulgaria. Land Use Policy, 27, 763-771. DOI: 10.1016/j.landusepol.2009.10.007.

Doležal, P., Pavlík, M., Střítecký, L., Dumbrovský, M. \& Martének J. (2010). Methodology for land consolidation implementation (in Czech). Praha: MZe - ÚPÚ.

Gorton, M. \& White J. (2003). The politics of agrarian collapse: decollectivisation in Moldova. East European Politics and Societies, 17(2), 305-331. DOI: 10.1177/0888325403017002006.

Janeček, M. et al. (2007). The agriculture soil conservation (in Czech). Praha: Výzkumný ústav meliorací a ochrany půdy v. v. i. Janeček, M. et al. (2012a): The agriculture soil conservation (in Czech). Praha: ČZU.

Janeček, M., Květoň, V., Kubátová, E. \& Kobzová D. (2012b). Differentiation and regionalization of rainfall erosivity factor values in the Czech Republic. Soil and Water Research, 7(1), 1-9. 
Kadlec, M. \& Toman F. (2002). Assessment of the vegetative cover (C) factor in dependence on climatic region (in Czech). In Bioklima - Prostředí - Hospodářství (pp. 544-550).

Lerman, Z. (2001). Agriculture in transition economies: from common heritage to divergence. Agricultural Economics, 26(2), 95-114. DOI: 10.1111/j.1574-0862.2001.tb00057.x.

Lobo, D., Lozano, Z. \& Delgado F. (2005): Water erosion risk assessment and impact on productivity of a Venezuelan soil. Catena, 64, 297-306. DOI: 10.1016/j.catena.2005.08.011.

McCool, D.K., Foster, G.R., Mutchler, C.K. \& Meyer L.D. (1989). Revised slope length factor for the Universal Soil Loss Equation. Trans. ASAE, 32, 1571-1576. DOI: 10.13031/2013.31192.

Mendez, M.J. \& Buschiazzo D.E. (2010). Wind erosion risk in agricultural soils under different tillage systems in the semiarid Pampas of Argentina. Soil Tillage Res., 106(2), 311-316. DOI: 10.1016/j.still.2009.10.010.

Mihara, M. (1996). Effects of agricultural land consolidation on erosion processes in Semi-Mountainous Paddy Fields of Japan. Journal of Agricultural Engineering Research, 64, 237-248. DOI: 10.1006/jaer.1996.0064.

Miranda, D., Crecente, R. \& Alvarez M.F. (2006). Land consolidation in land rural Galicia, N.W. Spain, since 1950: An example of the formulation and use of questions, criteria and indicators for evaluation of rural development policies. Land Use Policy, 23, 511-520. DOI: 10.1016/j.landusepol.2005.05.003.

Nyssen, J., Haile, M., Moeyersons, J., Poesen, J. \& Deckers J. (2000). Soil and water conservation in Tigray (Northern Ethiopia): the traditional daget technique and its integration with introduced techniques. Land Degrad. Dev., 11, 199-208. DOI: 10.1002/1099-145X(200005/06)11:3<199::AID-LDR376>3.0.CO.

Pašakarnis, G. \& Maliene V. (2010). Towards sustainable rural development in Central and Eastern Europe: Applying land consolidation. Land Use Policy, 27, 545-549. DOI: 10.1016/j.landusepol.2009.07.008

Pimentel, D., Harvey, C., Resosudarmo, P., Sinclair, K., Kurz, D., McNair, M., Crist, S., Shpritz, L., Fitton, L., Saffouri, R. \& Blair R. (1995). Environmental and economic costs of soil erosion and conservation benefits. Science, 267, 11171123. DOI: $10.1126 /$ science.267.5201.1117.

Prager, K., Prazan, J. \& Penov I. (2012). Soil conservation in transition countries: the role of institutions. Environmental Policy and Governance, 22(1), 55-73. DOI: 10.1002/eet.592.

Rey, F. (2009). A strategy for fine sediment retention with bioengineering works in eroded marly catchments in a mountainous Mediterranean climate (Southern Alps, France). Land Degrad. Dev., 20, 210-216. DOI: 10.1002/ldr.905.

Sikor, T, Müller, D. \& Stahl J. (2009). Land Fragmentation and Cropland Abandonment in Albania: Implications for the Roles of State and Community in Post-Socialist Land Consolidation. World Development, 37(8), 1411-1423. DOI: 10.1016/j.worlddev.2008.08.013.

Sklenička, P. (2006). Applying evaluation criteria for the land consolidation effect to three contrasting study areas in the Czech Republic. Land Use Policy, 23, 502-510. DOI: 10.1016/j.landusepol.2005.03.001.

Sklenička, P., Hladík, J., Střeleček, F., Kottová, B., Lososová, J., Číhal, L. \& Šálek M. (2009). Historical, environmental and socio-economic driving forces on land ownership fragmentation, the land consolidation effect and the project costs. Agricultural Economics, 55(12), 571-582.

Spaan, W.P., Winteraeken, H.J. \& Riksen M.J.P.M. (2006). Dutch policy and practices on erosion control: Then and now. Archives of Agronomy and Soil Science, 52(2), 233-241. DOI: 10.1080/03650340600603861.

Swinnen, J.F.M. (1999). The political economy of land reform choices in Central and Eastern Europe. Economics of Transition, 7(3), 637-664. DOI: 10.1111/1468-0351.00029.

van Dijk, T. (2007). Complications for traditional land consolidation in Central Europe. Geoforum, 38, 505-511. DOI: 10.1016/j.geoforum.2006.11.010

Vitikainen, A. (2004). An overview of land consolidation in Europe. Nordic Journal of Surveying and Real Estate Research, $1,25-44$.

Vjekoslav, P., Mario, N. \& Lari H. (2008). Influence of land consolidation on the competitiveness of Croatian agriculture. Cereal Res. Commun., 36(S), 1379-1382. DOI: 10.1556/CRC.36.2008.Suppl.2.

Vranken, L. \& Swinnen J. (2006). Land rental markets in transition: Theory and evidence from Hungary. World Development, 34(3), 481-500. DOI: 10.1016/j.worlddev.2005.07.017.

Wischmeier, W.H. \& Smith D.D. (1978). Predicting rainfall erosion losses: a guide to conservation planning. USDA Agr. Handbook 537.

Yanakieva, I. (2007). The agricultural land problems in Bulgaria and implementation of the Common Agricultural Policy. Agricultural Economics, 53, 189-193.

Zgłobicki, W. \& Baran-Zgłobicka B. (2012). Impact of loess relief on land use mosaic in SE Poland. Catena, 96, 76-82. DOI: $10.1016 /$ j.catena.2012.04.014. 